\title{
KAJIAN SISTEMATIS FAKTOR-FAKTOR YANG BERHUBUNGAN DENGAN RISIKO PSIKOSOSIAL PADA TENAGA KESEHATAN SAAT PANDEMI COVID-19
}

\author{
Cheryl Khairunnisa Miyanda ${ }^{1}$, Dadan Erwandi ${ }^{2}$ \\ Magister Keselamatan dan Kesehatan Kerja ${ }^{1}$, Departemen Keselamatan dan Kesehatan Kerja ${ }^{2}$ \\ Fakultas Kesehatan Masyaratakat, Universitas Indonesia \\ cheryl.khairunnisa01@ui.ac.id ${ }^{1}$, dadan@ui.ac.id ${ }^{2}$
}

\begin{abstract}
COVID-19 Pandemic has an impact on health care workers as the frontline of dealing with mortality and morbidity. This affects the work patterns and stress levels as psychosocial risk of health care workers. The study aims to analyse associated factors of stress as psychosocial risk among health care workers during the COVID-19 pandemic. Method: The design of this study used a systematic review with the PRISMA (Preferred Reporting Items for Systematic Reviews \& Meta Analyses) method. In the process of searching for data and information using databases from PubMed, ProQuest, Science Direct, Elsevier, and Sage journals. The keywords used during the search process are "associated factors, influencing factors, perceived, stress, mental health, healthcare workers, outbreak, pandemic, COVID19". Results: associated factors of stress as psychosocial risk among health care workers during pandemic included age, gender, profession, marital status, work experience, and Personal Protective Equipment (PPE). Conclusion: These factors must be considered to minimize the occurrence of errors and psychological complaints under managerial stress as psychosocial risk for health care workers during pandemic.
\end{abstract}

Keywords: Associated factors, stress, health care workers, COVID-19 pandemic

\begin{abstract}
ABSTRAK
Latar belakang: Pandemi COVID-19 memiliki dampak bagi tenaga kesehatan sebagai garda terdepan penangggulangan angka kesakitan dan kematian. Hal ini berpengaruh terhadap pola kerja dan tingkat stres sebagai risiko psikososial tenaga kesehatan. Tujuan penelitian ini untuk menganalisis faktor yang berhubungan dengan stres sebagai risiko psikososial pada tenaga kesehatan di masa pandemic COVID19. Metode: Studi ini menggunakan desain tinjauan sistematis dengan metode PRISMA (Preferred Reporting Items for Systematic Reviews \& Meta-Analyses). Dalam melakukan pencarian informasi dan data menggunakan database yang berasal dari PubMed, ProQuest, Science Direct, Elsevier dan Sage journals. Kata kunci yang digunakan mengolaborasikan associated factors, influencing factors, perceived, stres, mental health, healthcare workers, outbreak, pandemic, COVID-19. Hasil: Faktor yang berhubungan dengan stres pada tenaga kesehatan di masa pandemi diantaranya usia, jenis kelamin, profesi, status pernikahan, pengalaman kerja, dan alat pelindung diri (APD). Kesimpulan: Faktor-faktor tersebut harus dipertimbangkan untuk meminimalisir terjadinya error maupun keluhan psikologis dalam bekerja dalam manajerial stres sebagai risiko psikososial pada tenaga kesehatan di masa pandemi.
\end{abstract}

Kata kunci: Faktor yang berhubungan, stres, pekerja tenaga kesehatan, pandemic COVID-19

\section{PENDAHULUAN}

Pada akhir tahun 2019, dunia digemparkan dengan penemuan Novel Coronavirus Disease (COVID-19) (Xiang, et al, 2020). Dalam hal ini, World Health Organization (WHO) menyatakan bahwa kasus ini akan menjadi sebuah pandemi serta dapat berdampak kepada populasi yang memiliki risiko kesehatan tinggi dengan sistem fasilitas kesehatan yang rendah (WHO, 2020). Kasus ini menyebabkan kebutuhan terkait fasilitas 
kesehatan meningkat pada sebagian besar negara di dunia.

Pekerja tenaga kesehatan merupakan garda terdepan dalam menurunkan angka kesakitan hingga kematian akibat dampak COVID-19. Namun, tenaga kesehatan merupakan pekerjaan berisiko tinggi terhadap penularan COVID-19. Tantangan utama dalam pandemi COVID-19 adalah merawat pasien yang terinfeksi, hal ini membutuhkan kontak terus menerus dengan waktu yang lama. Infeksi dan kematian yang meluas pada tenaga kesehatan yang dilaporkan pada pandemi MERS, SARS, dan COVID-19 memberikan tekanan sosial dan mental yang cukup besar (Almutairi et al., 2018). Akibat dari pandemi menyebabkan peningkatan beban kerja dan perpanjangan waktu kerja bagi tenaga kesehatan. Di sisi lain, tenaga kesehatan juga menjaga jarak dari keluarga dan anak-anak mereka serta mengarantina diri sendiri di masa pandemi (Nguyen, et al, 2021).

Studi menunjukkan bahwa pekerjaan yang berpotensi menimbulkan stres sebagai risiko psikososial lebih mungkin menyebabkan kelelahan kerja (Embriaco et al., 2007). Kelelahan kerja dapat menyebabkan penurunan dalam kepemimpinan, kualitas perawatan medis yang rendah, tingkat kepuasan pasien rawat inap yang berkurang, peningkatan tingkat infeksi, dan tingkat kematian yang lebih tinggi diantara pasien (Dyrbye et al., 2019). Tenaga kesehatan sangat rentan terhadap kelelahan kerja karena terpapar stres terkait pekerjaan dalam jumlah besar (Elshaer et al., 2019). Stres sebagai risiko psikososial tidak hanya membahayakan kesehatan dan kesejahteraan individu, tetapi juga terkait dengan frekuensi kesalahan medis dan kualitas layanan kesehatan. Peningkatan stres sebagai risiko psikososial pada pekerja tenaga kesehatan merupakan hal yang tidak bisa dipandang sebelah mata, karena dapat berimplikasi psikologis jangka panjang (aly et al, 2021). Berdasarkan pernyataan diatas, penting untuk mengetahui faktor-faktor yang berkontribusi menyebabkan stres sebagai risiko psikososial pada tenaga kesehatan di masa pandemi COVID-19 menggunakan studi publikasi yang telah melakukan penelitian terhadap topik terkait.

\section{METODE}

Studi ini menggunakan metode PRISMA (Preferred Reporting Items for Systematic Reviews \& Meta-Analyses) yang dilakukan secara sistematis dengan mengikuti tahapan penelitian dengan benar. Pencarian artikel penelitian yang relevan dengan topik penelitian ini dilakukan dengan menggunakan kolaborasi kata kunci: associated factors, influencing factors, perceived, stres, mental health, healthcare workers, outbreak, pandemic, COVID-19 dari PubMed sebanyak 29 jurnal, ProQuest sebanyak 55 jurnal, Science Direct sebanyak 87 jurnal, Elsevier sebanyak 42 jurnal dan Sage journals sebanyak 19 jurnal. Adapun kriteria inklusi dalam sistematika review, peneliti menggunakan studi original terkait topik yang bukan merupakan studi kajian sistematis, studi kuantitatif menggunakan berbagai macam rancangan studi, studi internasional, terpublikasi pada 2020-2021, termasuk ke dalam Q1-Q3 dan akses studi terbuka. Peneliti menemukan 232 studi terkait yang dapat dipilih kembali menggunakan metode PRISMA. 

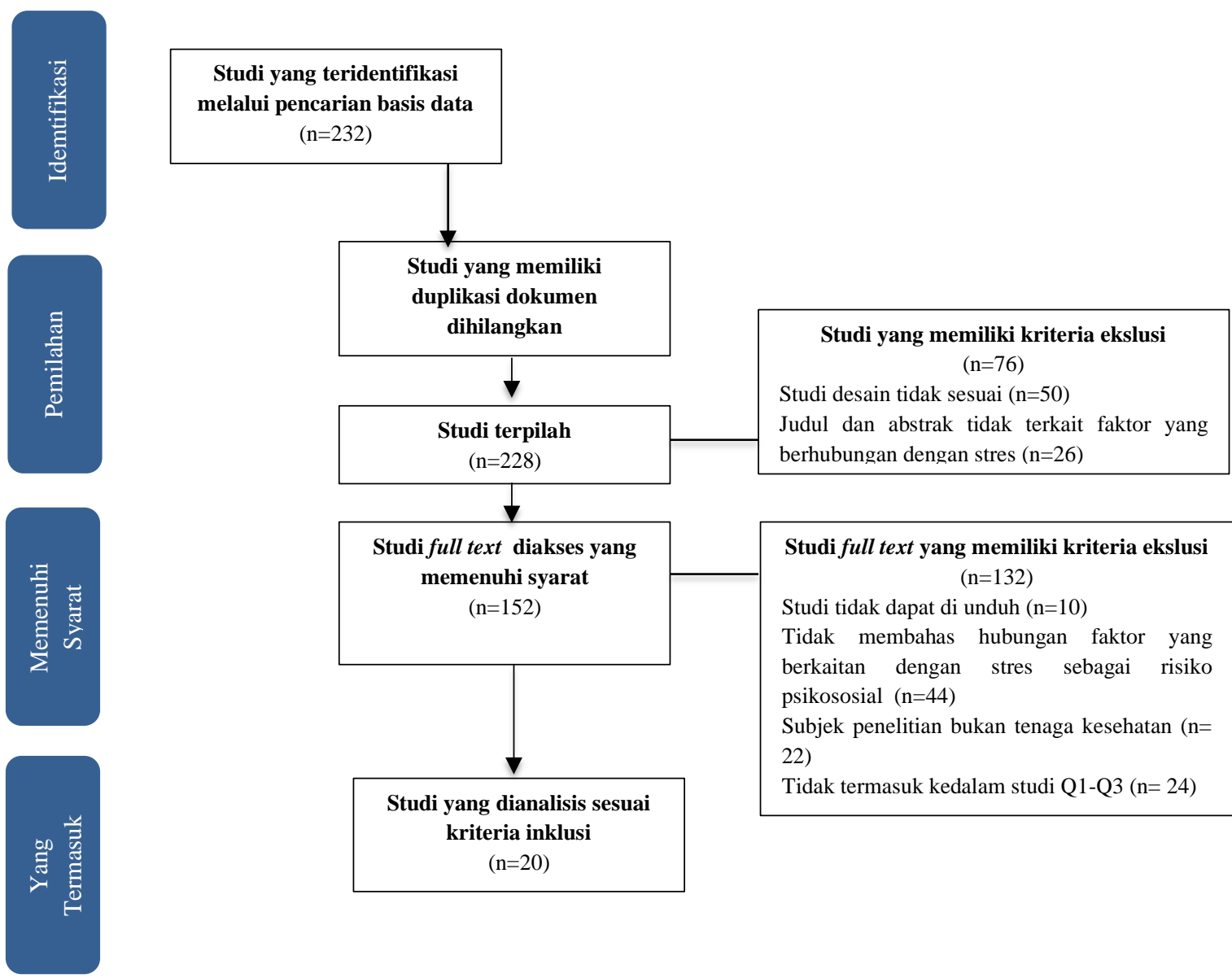

\section{Gambar 1. Proses Ekstraksi Literatur Review Menggunakan Metode PRISMA}

Identifikasi awal dimulai dari pengumpulan dokumen melalui pencarian basis data (PubMed, ProQuest, Science Direct, Elsevier, dan Sage journals) sebanyak 232 jurnal. Selanjutnya adalah proses pemilahan, dimana dilakukan seleksi untuk dokumen yang memiliki duplikasi, hasil studi terpilah sebanyak 228 jurnal, dilanjutkan dengan pemilahan kriteria eksklusi sebanyak 76 jurnal dengan rincian studi desain yang tidak sesuai sebanyak 50 jurnal serta judul dan abstrak tidak terkait faktor yang berhubungan dengan stres sebanyak 26 jurnal. Berikutnya didapatkan studi full text diakses yang memenuhi syarat sebanyak 152 jurnal, dilakukan kembali pemilahan kriteria eksklusi sebanyak 132 jurnal dengan rincian studi yang tidak dapat diunduh sebanyak 10 jurnal, tidak membahas hubungan faktor yang berkaitan dengan stres sebagai risiko psikososial sebanyak 44 jurnal, subjek penelitian bukan tenaga kesehatan sebanyak 22 jurnal, dan tidak termasuk kedalam studi Q1-Q3 sebanyak 24 jurnal. Hasil akhir dari proses penyaringan tersebut didapatkan studi yang akan di analisis sesuai dengan kriteria inklusi sebanyak 20 jurnal.

\section{HASIL}

Berdasarkan pencarian literatur menggunakan metode PRISMA, 20 studi ditemukan pada tahun 2020-2021, dengan kriteria inklusi yang telah ditentukan. 
Tabel 1. Hasil Penelusuran Literatur

\begin{tabular}{|c|c|c|c|c|}
\hline No & Penulis, Tahun, Judul & Lokasi & $\begin{array}{c}\text { Faktor yang } \\
\text { Berhubungan dengan } \\
\text { Stres }\end{array}$ & $P$-value \\
\hline 1 & $\begin{array}{l}\text { William Wilson, Jeffrey Pradeep Raj, Seema Rao, } \\
\text { Murtuza Ghiya, Nisanth Menon } \\
\text { Nedungalaparambil, Harshit Mundra, Roshan } \\
\text { Mathew. 2020. Prevalence and Predictors of } \\
\text { Stress, Anxiety, and Depression Among } \\
\text { Healthcare Workers Managing COVID-19 } \\
\text { Pandemic in India: A Nationwide Observational } \\
\text { Study }\end{array}$ & India & - Jenis kelamin (wanita) & 0,02 \\
\hline 2 & $\begin{array}{l}\text { Eng Sing Lee, FAMS, PhD, Shu Yun Tan, } \\
\text { MBBS, MMed, Poay Sian Sabrina Lee, } \\
\text { BBiomedSc(Hons), PhD, Hui Li Koh, } \\
\text { BSc(Hons), BEc, Shok Wen Winnie Soon, } \\
\text { MMed, FAMS, Kang Sim, MMed, FAMS, Wern } \\
\text { Ee Tang, MBBS, MMed, Phui-Nah Chong, } \\
\text { MBBS, MMed. 2020. Perceived Stress and } \\
\text { Associated Factors Among Healthcare Workers } \\
\text { in A Primary Healthcare Setting: The } \\
\text { Psychological Readiness and Occupational } \\
\text { Training Enhancement during COVID-19 Time } \\
\text { (PROTECT) Study. }\end{array}$ & Singapura & $\begin{array}{l}\text { Status pernikahan } \\
\text { (menikah) } \\
\text { Pengaturan kehidupan saat } \\
\text { ini (hidup bersama orang } \\
\text { lain) } \\
\text { Pengaruh langsung oleh } \\
\text { COVID-19 } \\
\text { Pelatihan, proteksi, dan } \\
\text { support }\end{array}$ & $\begin{array}{l}<0,001 \\
<0,001\end{array}$ \\
\hline 3 & $\begin{array}{l}\text { Nhan Phuc Thanh Nguyen, Duong Dinh Le, } \\
\text { Robert Colebunders, Joseph Nelson Siewe Fodjo, } \\
\text { Trung Dinh Tran, Than Van Vo. 2021. Stress and } \\
\text { Associated Factors among Frontline Healthcare } \\
\text { Workers in the COVID-19 Epicenter of Da Nang } \\
\text { City, Vietnam. }\end{array}$ & Vietnam & $\begin{array}{l}\text { Jumlah keseluruhan jam } \\
\text { kerja } \\
\text { Keyakinan dalam } \\
\text { ketersediaan APD } \\
\text { Pengetahuan yang dimiliki } \\
\text { terkait pencegahan dan } \\
\text { pengobatan COVID-19 } \\
\text { Profesi fasilitas kesehatan } \\
\text { (farmasi, perawat, pekerja } \\
\text { laboratorium, pekerja } \\
\text { kesehatan masyarakat) }\end{array}$ & $\begin{array}{l}0,011 \\
0,031\end{array}$ \\
\hline 4 & $\begin{array}{l}\text { Yigrem Ali Chekole, Solomon Yimer Minaye, } \\
\text { Semagn Mekonnen Abate, and Birhanie } \\
\text { Merkuriaw. 2020. Perceived Stress and Its } \\
\text { Associated Factors during COVID-19 among } \\
\text { Healthcare Provirders in Ethiopia: A Cross- } \\
\text { Sectional Study. }\end{array}$ & Ethiopia & $\begin{array}{l}\text { Umur } \\
\text { Status pernikahan } \\
\text { Kualifikasi } \\
\text { Profesi dari partisipan } \\
\text { Pengalaman bekerja }\end{array}$ & $\begin{array}{l}<0,01 \\
<0,01 \\
<0,01 \\
<0,01 \\
<0,01\end{array}$ \\
\hline 5 & $\begin{array}{l}\text { Apsara Pandey, } \\
\text { Chandrakala Sharma, } \\
\text { Ram Hari Chapagain, } \\
\text { Narmada Devkota, } \\
\text { Kamal Ranabhat, Suman } \\
\text { Pant, Kriti Adhikari. 2020. Stress, Anxiety, } \\
\text { Depression and Their Associated Factors among } \\
\text { Health Care Workers During COVID-19 in } \\
\text { Nepal. }\end{array}$ & Nepal & $\begin{array}{l}\text { Jenis kelamin } \\
\text { Umur } \\
\text { Status pernikahan } \\
\text { Pekerjaan } \\
\text { Berkeluarga atau tinggal } \\
\text { bersama keluarga } \\
\text { Ketidaktersediaan APD } \\
\text { Bekerja lebih dari } 40 \text { jam } \\
\text { per-minggu } \\
\text { Menghadapi kesulitan } \\
\text { ketika lockdown }\end{array}$ & $\begin{array}{l}0,004 \\
0,043 \\
0,001 \\
0,0054 \\
0,0032 \\
0,0023 \\
0,002 \\
0,004\end{array}$ \\
\hline 6 & $\begin{array}{l}\text { Vittorio Lenzo, Maria C. Quattropani, Alberto } \\
\text { Sardella, Gabriella Martino and George A. } \\
\text { Bonanno. 2021. Depression, Anxiety, and Stress } \\
\text { Among Healthcare Workers During the COVID- } \\
19 \text { Outbreak and Relationships with Expressive } \\
\text { Flexibility and Context Sensitivity. }\end{array}$ & Italia & Umur & 0,001 \\
\hline
\end{tabular}




\begin{tabular}{|c|c|c|c|c|}
\hline 7 & $\begin{array}{l}\text { Gilbert T. Chua Keith T. S. Tung Mike Yat Wah } \\
\text { Kwan Rosa S. Wong Celine S. L. Chui, Xue Li, } \\
\text { Wilfred H. S. Wong Winnie W. Y. Tso King Wa } \\
\text { Fu Ko Ling Chan Yun Kwok Wing Eric Yu Hai } \\
\text { Chen, Tatia Mei Chun Lee Nirmala Rao Godfrey } \\
\text { C. F. Chan Ellis K. L. Hon Ivan Fan Ngai Hung } \\
\text { Kui Kai Lau Marco H. K. Ho Kirstie Wong } \\
\text { Xiaoli Xiong Shuiqing Chi Shao-tao Tang Paul K. } \\
\text { H. Tam, Ian C. K. Wong and Patrick Ip. 2021. } \\
\text { Multilevel Factors Affecting Healthcare Workers } \\
\text { Perceived Stress and Risk of Infection During } \\
\text { COVID-19 Pandemic. }\end{array}$ & $\begin{array}{l}\text { Hong } \\
\text { Kong }\end{array}$ & $\begin{array}{l}\text { Peran pada pekerjaan } \\
\text { Hubungan dengan } \\
\text { keluarga selama pandemi } \\
\text { COVID-19 } \\
\text { Kepuasan dengan seluruh } \\
\text { kebijakan khusus }\end{array}$ & $\begin{array}{l}0,001 \\
0,025\end{array}$ \\
\hline 8 & $\begin{array}{l}\text { Deldar Morad Abdullah, Ayad Ahmad Mohamed. } \\
\text { 2020. The Concequences of the COVID-19 } \\
\text { Pandemic On Perceived Stress in Clinical } \\
\text { Practice: Experience of Doctors in Iraqi } \\
\text { Kurdistan. }\end{array}$ & $\begin{array}{l}\text { Iraqi } \\
\text { Kurdistan }\end{array}$ & $\begin{array}{l}\text { Spesialisasi kedokteran } \\
\text { Jenis Kelamin }\end{array}$ & $\begin{array}{l}0,018 \\
0,001\end{array}$ \\
\hline 9 & $\begin{array}{l}\text { Seshadri Sekhar Chatterjee, Ranjan } \\
\text { Bhattacharyya, Sumita Bhattacharyya, Sukanya } \\
\text { Gupta, Soumitra Das, Bejoy Bikram Banerjee. } \\
\text { 2020. Attitude, Practice, } \\
\text { Behavior, and Mental Health Impact of COVID- } \\
19 \text { on Doctors. }\end{array}$ & India & Pengalaman bekerja & 0,030 \\
\hline 10 & $\begin{array}{l}\text { Mohd Fadhli Mohd Fauzi, Hanizah Mohd Yusoff, } \\
\text { Rosnawati Muhamad Robat, Nur Adibah Mat } \\
\text { Saruan, Khairil Idham Ismail, Ahmad Firdaus } \\
\text { Mohd Haris. 2020. Doctors Mental Health in the } \\
\text { Midst of COVID-19 Pandemic: The Roles of } \\
\text { Work Demands and Recovery Experiences. }\end{array}$ & Malaysia & $\begin{array}{l}\text { Tuntutan pekerjaan } \\
\text { Pengalaman pemulihan }\end{array}$ & $\begin{array}{l}<0,001 \\
<0,001\end{array}$ \\
\hline 11 & $\begin{array}{l}\text { Min Leng MSN, RN, Lili Wei PHD, RN, Xiaohui } \\
\text { Shi BSN, MSN, Guorong Cao BSN, RN, Yuling } \\
\text { Wei MSN, RN, Hong Xu BSN, RN, Xiaoting } \\
\text { Zhang BSN, RN, Wenwen Zhang BSN, RN, } \\
\text { MSN, Shuyun Xing MSN, RN, Holly Wei PhD, } \\
\text { RN, CPN, NEA-BC. 2020. Mental Distress and } \\
\text { Influencing Factors in Nurse Caring for Patients } \\
\text { With COVID-19. }\end{array}$ & China & Umur & 0,04 \\
\hline 12 & $\begin{array}{l}\text { Beesan Maraqa, Zaher Nazzal, Therese Zink. } \\
\text { 2020. Palestinian Health Care Workers Stress } \\
\text { and Stresors During COVID-19 Pandemic: A } \\
\text { Cross-Sectional Study. }\end{array}$ & Palestina & $\begin{array}{l}\text { Mendapatkan pelatihan } \\
\text { penanganan pandemi } \\
\text { Merasa kecewa ketika } \\
\text { bekerja pada situasi } \\
\text { pandemi } \\
\text { Pemikiran kuat terkait cuti } \\
\text { sakit }\end{array}$ & $\begin{array}{l}<0,001 \\
<0,001\end{array}$ \\
\hline 13 & $\begin{array}{l}\text { Mustafa Kursat Sahin, Servet Aker, Gulay Sahin, } \\
\text { Aytul Karabekiroglu. 2020. Prevalence of } \\
\text { Depression, Anxiety, Distress, and Insomnia and } \\
\text { Related Factors in Healthcare Workers During } \\
\text { COVID-19 Pandemic in Turkey. }\end{array}$ & Turki & $\begin{array}{l}\text { Jenis kelamin } \\
\text { Pekerjaan } \\
\text { Penyakit kronis } \\
\text { Penyakit psikiatri } \\
\text { Dukungan psikiatri } \\
\text { Penyakit COVID-19 }\end{array}$ & $\begin{array}{l}<0,001 \\
<0,001 \\
0,021 \\
<0,001 \\
<0,001 \\
0,025\end{array}$ \\
\hline 14 & $\begin{array}{l}\text { Lorena Garcia Fernandex, Veronica Romero } \\
\text { Ferreiro, Pedro David Lopez, Sergio Padilla, } \\
\text { Irene Calero Sierra, Maria Monzo Garcia, Jorge } \\
\text { Perez Martin, Roberto Rodriguez Jimenez. } 2020 . \\
\text { Mental Health Impact of COVID-19 Pandemic on } \\
\text { Spanish Healthcare Worker. }\end{array}$ & Spanyol & $\begin{array}{l}\text { Ketidaktersediaan } \\
\text { informasi COVID-19 } \\
\text { Ketertidaksediaan APD }\end{array}$ & $\begin{array}{l}0,001 \\
0,001\end{array}$ \\
\hline 15 & $\begin{array}{l}\text { Rodolfo Rossi, MD, Valentina Socci, Ph.D., } \\
\text { Fransesca Pacitti, MD, Giorgio Di Lorenzo, MD, }\end{array}$ & Italia & $\begin{array}{l}\text { Umur } \\
\text { Jenis kelamin (wanita) }\end{array}$ & $\begin{array}{l}0,002 \\
0,001\end{array}$ \\
\hline
\end{tabular}




\begin{tabular}{|c|c|c|c|c|}
\hline & $\begin{array}{l}\text { Antinisca Di Marco, Ph.D, Alberto Siracusano, } \\
\text { MD, Alessandro Rossi, MD. 2020. Mental } \\
\text { Health Outcomes Among Frontline and Second } \\
\text { Line Health Care Workers During the Corona } \\
\text { Virus Disease } 2019 \text { (COVID-19) Pandemic in } \\
\text { Italy. }\end{array}$ & & $\begin{array}{l}\text { Terinfeksi dan dirawat di } \\
\text { rumah sakit } \\
\text { Terinfeksi dan karantina } \\
\text { di rumah }\end{array}$ & $\begin{array}{l}0,001 \\
0,002\end{array}$ \\
\hline 16 & $\begin{array}{l}\text { Handan Alan, Ph.D, RN, Feride Eskin Bazaksiz, } \\
\text { PH.D, RN, Hanife Tiryaki Sen, Ph.D, RN, Gulcan } \\
\text { Taskiran Eskici, Ph.D, RN, Emel Gumus, M.Sc, } \\
\text { RN, Arzu, K. Harmanci Seren, Ph.D, RN. 2020. } \\
\text { "i'm a hero, but..”.: An Evaluation of Depression, } \\
\text { Anxiety, and Stress Levels of Fronline Healthcare } \\
\text { Proffesionals During COVID-19 Pandemic in } \\
\text { Turkey. }\end{array}$ & Turki & $\begin{array}{l}\text { Umur } \\
\text { Jenis kelamin } \\
\text { Profesi } \\
\text { Memberikan perawatan } \\
\text { kepada pasien COVID-19 } \\
\text { Persepsi tingkat risiko } \\
\text { COVID-19 dalam } \\
\text { kemungkinan terinfeksi } \\
\text { Frekuensi mengikuti } \\
\text { berita COVID-19 di media } \\
\text { sosial }\end{array}$ & $\begin{array}{l}0,001 \\
0,001 \\
0,001 \\
0,003 \\
0,000\end{array}$ \\
\hline 17 & $\begin{array}{l}\text { Alessandra Babore, Lucia Lombardi, Maria Luisa } \\
\text { Viceconti, Silvia Pignataro, Valentina Marino, } \\
\text { Monia Crudele, Carla Candelori, Sonia Monique } \\
\text { Bramanti, Carmen Trumello. 2020. } \\
\text { Psychological Effects of The COVID-19 } \\
\text { Pandemic: Perceived Stress and Coping } \\
\text { Strategies Among Healthcare Proffessionals. }\end{array}$ & Italia & $\begin{array}{l}\text { Sikap positif } \\
\text { Suport sosial } \\
\text { Bekerja/ tidak bekerja } \\
\text { dengan pasien COVID-19 } \\
\text { Strategi penghindaran }\end{array}$ & $\begin{array}{l}0,000 \\
0,000 \\
0,000 \\
0,002\end{array}$ \\
\hline 18 & $\begin{array}{l}\text { Zarintaj Hosseinzadeh Shanjani, Khadijeh } \\
\text { Hajimiri, Bahram Rostami, Shokoufeh Ramezani, } \\
\text { Mohsen Dadashi. 2020. Stress, Anxiety, and } \\
\text { Depression Levels Among Healthcare Staff } \\
\text { During the COVID-19 Epidemic. }\end{array}$ & Iran & $\begin{array}{l}\text { Status pernikahan } \\
\text { Level edukasi } \\
\text { Posisi organisasi }\end{array}$ & $\begin{array}{l}-0,022 \\
-0,022 \\
0,009\end{array}$ \\
\hline 19 & $\begin{array}{l}\text { Lei Huang, Yun Wang, Juan Liu, Pengfei Ye, } \\
\text { Xijian Chen, Huayan Xu, Yingkun Guo, Haibo } \\
\text { Qu, Gang Ning. 2021. Short Report: Factors } \\
\text { Determining Perceived Stress Among Medical } \\
\text { Staff in Radiology Departements During the } \\
\text { COVID-19 Outbreak. }\end{array}$ & China & $\begin{array}{l}\text { Kecemasan yang ada } \\
\text { Ketakutan dalam } \\
\text { terinfeksi aat bekerja } \\
\text { Pengetahuan yang baik } \\
\text { mengenai COVID-19 } \\
\text { Ketakutan akan wabah } \\
\text { yang tidak terkendali } \\
\text { Jenis kelamin (wanita) } \\
\text { Klasifikasi rumah sakit } \\
\text { yang lebih tinggi }\end{array}$ & $\begin{array}{l}<0,001 \\
0,001 \\
<0,001 \\
0,022 \\
0,026 \\
0,042\end{array}$ \\
\hline 20 & $\begin{array}{l}\text { Ghada Shahrour, Ph.D, PMHCNS, RN, Latefa Ali } \\
\text { Dardas, Ph.D, PHMN. 2020. Acute Stress } \\
\text { Disorder, Coping Self-Efficacy and Subquent } \\
\text { Psychological Distres among Nurses Amid } \\
\text { COVID-19. }\end{array}$ & Yordania & $\begin{array}{l}\text { Umur } \\
\text { Stres akut } \\
\text { Mengatasi efikasi diri }\end{array}$ & $\begin{array}{l}0,026 \\
0,000 \\
0,032\end{array}$ \\
\hline
\end{tabular}

\section{PEMBAHASAN}

Dari hasil kaji literatur, peneliti mengategorikan distribusi faktor yang bepengaruh menjadi sebuah tabel ekstraksi yang menjelaskan signifikansi faktor-faktor yang berpengaruh terhadap hubungan stres di masa pandemi COVID-19. Dari hasil ekstraksi didapatkan faktor usia oleh (Chekole, et al. 2020; Pandey, et al. 2020; Lenzo, et al. 2021; Leng, et al. 2020; Rossi, et al. 2020; Alan, et al. 2020; Shahrour, et al. 2020), jenis kelamin oleh (Willson, et al. 2020; Pandey, et al. 2020; Abdullah, et al. 2020; Sahin, et al. 2020; Rossi, et al. 2020; Alan, et al. 2020; Huang, et al. 2021), profesi oleh (Nguyen, et al. 2021; Chekole, et al. 2020; Pandey, et al. 2020; Gilbert, et al. 2021; Abdullah, et al. 2020; Sahin, et al. 2020; Alan, et al. 2020; Shanjani, et al. 
2020), status pernikahan oleh (Lee, et al. 2020; Chekole, et al. 2020; Pandey, et al. 2020; Shanjani, 2018), pengalaman kerja oleh (Lenzo, et al. 2021; Chatterjee, et al. 2020), dan alat pelindung diri (APD) oleh (Lee, et al. 2020; Nguyen, et al. 2021; Pandey, et al. 2020; Fernandex, et al. 2020) memiliki hubungan terhadap stres sebagai risiko psikososial pada tenaga kesehatan di masa pandemi COVID-19.

\section{Faktor Usia}

Beberapa penelitian mengemukakan individu yang lebih dewasa ditemukan lebih mudah stres. Stephen \& Adams (2021) menunjukkan hasil bahwa individu dengan umur 56 tahun ke atas lebih mudah untuk stres dibandingkan umur dibawahnya. Hasil tersebut juga berbanding lurus dengan penelitian yang dilakukan oleh Lee, et al (2020) yang menunjukan hasil umur 25-31 lebih merasakan stres dibandingkan dengan umur 18-24. Hal tersebut dapat disebabkan oleh hubungan antara usia dengan tingkat keparahan akibat COVID-19, dimana individu yang lebih dewasa lebih berisiko tinggi terhadap virus tersebut (Alnazly, E, et al, 2021). Situasi COVID-19 memperburuk lanjut usia dengan meningkatkan rasa takut, panik atau khawatir pada kematian karena terinfeksi, atau terisolasi dari keluarga, selain itu perasaan kesepian, gelisah, dampak keuangan, penyakit bawaan yang sudah ada sebelumnya, aktivitas fisik yang terbatas terkait dengan tingkat ketakutan serta tekanan psikologis pada usia yang lebih tua selama COVID-19 (Yadav U., et al. 2021). Pada tenaga kesehatan dengan usia lebih tua harus memiliki perhatian lebih karena memiliki potensi terinfeksi lebih besar yang disebabkan oleh intervensi dan perawatan langsung kepada pasien COVID-19. Kebutuhan psikologis pada usia lebih tua perlu diperhatikan, dengan membangun dan mengintegrasikan dukungan kesehatan mental sebagai bagian dari rencana kesiapsiagaan dan respon COVID-19 dalam memerangi ketakutan mereka
(Yadav U., et al. 2021). Bentuk manajerial stres sebagai risiko psikososial pada usia yang berisiko tinggi salah satunya yakni dilakukan pelatihan di masa pandemi secara bekala (Boyaci et al., 2014).

\section{Faktor Jenis Kelamin}

Beberapa hasil penelitian memperlihatkan hasil yang berbeda antara tingkat stres tenaga kesehatan pria dan wanita. Temuan ini berbanding lurus dengan penelitian yang dilakukan oleh (William et al., 2021; Pandey et al., 2020; Abdulah \& Mohammed, 2020; Sahin et al., 2020; Rossi et al., 2020; Alan et al., 2020; Huang, L et al., 2021) bahwa tenaga kesehatan wanita cenderung lebih mungkin menderita stres dibandingkan dengan pria. Sebagian besar responden wanita mengalamani stres sebagai risiko psikososial, hal ini dikarenakan pria lebih mampu mengutamakan akal daripada perasaaan mereka, sedangkan wanita menggunakan perasaan mereka lebih dalam menghadapi suatu masalah (Zhang et al, 2020).

\section{Faktor Profesi}

Faktor spesialisasi pekerjaan berpengaruh signifikan karena merupakan prediktor independen stres sebagai risiko psikososial (Nguyen, et al, 2021; Chekole et al., 2020; Pandey et al., 2020; Chua et al., 2021; Abdulah \& Mohammed, 2020; Sahin et al., 2020; Alan et al., 2020; Shanjani et al., 2020; Huang et al., 2021). Menurut penelitian yang dilakukan oleh Chekole et al. (2021) Perawat dan pekerja laboratorium lebih merasakan stres dibandingkan oleh dokter. Hal tersebut juga mendukung kepada penelitian yang dilakukan oleh Nguyen, et al (2021) menyatakan perawat serta pekerja laboratorium memiliki tingkat dan merasakan stres sebagai risiko psikososial lebih tinggi dibandingkan dengan profesi kesehatan lainnya. Pekerja laboratorium mengambil darah maupun sampel swab hidung maupun tenggorokan. Penanganan dari pasien yang terinfeksi dapat 
meningkatkan risiko pajanan yang mengarah pada peningkatan stres sebagai risiko psikososial. Perawat menghabiskan banyak waktu dengan pasien COVID-19 dibandingkan dengan petugas kesehatan lainnya, hal ini juga dapat meningkatkan stres terhadap profesi perawat (Pandey, et al, 2020). Tidak hanya perawat serta pekerja laboratorium, dokter juga memiliki tingkat stres yang tinggi dikarenakan melakukan pemeriksaan pada pasien COVID-19 secara langsung (Abdulah \& Mohammed, 2020).

\section{Faktor Status Pernikahan}

Status pernikahan juga terkait dengan hubungan antara stres sebagai risiko psikososial pada tenaga kesehatan, penelitian yang dikemukakan oleh (Lee et al, 2020; Chekole et al, 2020; Pandey et al, 2020; Shanjani et al, 2020) melaporkan bahwa tenaga kesehatan yang sudah menikah lebih mungkin menderita stres sebagai risiko psikososial, hal ini dikarenakan ketakutan dalam penularan COVID-19 kepada keluarga maupun dapat terisolasi dari keluarga mereka. Hal tersebut juga didukung oleh pernyataan MPHSS (2020) yang menyatakan bahwa rasa cemas saat merawat pasien COVID-19 yang dialami oleh tenaga kesehatan adalah rasa takut menularkan virus tersebut kepada teman dan juga keluarga.

\section{Faktor Pengalaman Kerja}

Pada beberapa penelitian, faktor pengalaman bekerja juga berhubungan dengan tingkat stres sebagai risiko psikososial pada tenaga kesehatan di masa pandemi. Penelitian yang di lakukan oleh Rose et al (2021) mengemukakan bahwa profesi dengan pengalaman kerja terlebih dengan situasi dan kondisi yang sama seperti SARS dan H1N1 memiliki kondisi psikologis yang siap dengan situasi pandemi yang akan mendatang. Dalam menghadapi wabah, diperlukan kemampuan beradaptasi dan mengatasi kesulitan, hal ini disebut dengan ketahanan. Suatu penelitian menunjukan bahwa ketahanan dapat menjadi faktor pelindung dari stres, kecemasan, dan depresi. Hal ini dapat disimpulkan bahwa ketahanan berhubungan dengan tingkat stres, kecemasan tenaga kesehatan, dalam arti semakin tinggi tingkat ketahanan individu semakin baik kesehatan mental tersebut (Gheslagh RG et al., 2017). Ketahanan merupakan kemampuan individu dalam keadaan normal ketika menghadapi suatu peristiwa yang berpotensi mengganggu fisik dan mental, dari ketahanan tersebut berdampak pada penjagaan kemampuan kestabilan (Bonanno GA, 2004). Ketahanan bisa didapatkan dari pengalaman bekerja sebelumnya, seperti pengalaman kerja pada wabah sebelumnya.

\section{Faktor Alat Pelindung Diri}

Para tenaga kesehatan diwajibkan memakai Alat Pelindung Diri (APD) yang dikenakan untuk menjaga diri dari infeksi, namun hal ini merupakan salah satu faktor yang mempengaruhi tingkat stres sebagai risiko psikososial, dimana tenaga kerja memiliki kecemasan dengan APD yang tidak memadai. Hal ini dijelaskan pada penelitian (Lee et al., 2020; Nguyen et al., 2021; Pandey et al., 2020; Rossi et al., 2020) APD merupakan hal penting bagi tenaga kesehatan karena mencegah terjadinya infeksi terhadap diri sendiri maupun keluarga. Tanpa APD yang memadai tenaga kesehatan lebih berpotensi untuk terinfeksi. Penurunan pasokan layanan kesehatan dan dikombinasikan dengan permintaan perawatan kesehatan yang meningkat menyebabkan ketidakstabilan pada infrastruktur kesehatan, hal tersebut menyebabkan kualitas dan kuantitas perawatan yang tersedia. Petugas kesehatan yang sakit juga dapat menjadi sumber penularan bagi masyakarat sekitarnya. APD menjadi komponen kunci dalam pencegahan dan pengendalian infeksi (Cohen \& Rodgers, 2020). APD yang memadai bagi tenaga kesehatan dapat menurunkan tingkat stres karena memiliki persepsi keamanan bagi pengguna (Larson et al., 2011). 


\section{KESIMPULAN}

Pada sistematika review ditemukan faktor yang mempengaruhi stres sebagai risiko psikososial pada tenaga kerja kesehatan di masa pandemi COVID-19 diantaranya umur, jenis kelamin, profesi tenaga kesehatan, status pernikahan, pengalaman bekerja, serta alat pelindung diri (APD) yang memadai. Untuk pengelolaan dan manajerial stres sebagai risiko psikososial pada tenaga kesehatan di era pandemi COVID-19 harus mempertimbangkan faktor-faktor tersebut untuk meminimalisir terjadinya error maupun keluhan psikologis dalam bekerja.

\section{UCAPAN TERIMA KASIH}

Penulis mengucapkan terima kasih kepada pembimbing dan teman-teman yang telah membantu berjalannya pengumpulan data serta penyusunan tulisan ini.

\section{DAFTAR PUSTAKA}

Abdulah, D. M., \& Mohammed, A. A. (2020). The consequences of the COVID-19 pandemic on perceived stres in clinical practice: experience of doctors in Iraqi Kurdistan. Romanian Journal of Internal Medicine $=$ Revue Roumaine de Medecine Interne, 58(4), 219-227.

https://doi.org/10.2478/rjim-20200020

Alan, H., Eskin Bacaksiz, F., Tiryaki Sen, H., Taskiran Eskici, G., Gumus, E., \& Harmanci Seren, A. K. (2021). "I'm a hero, but...": An evaluation of depression, anxiety, and stres levels of frontline healthcare professionals during COVID-19 pandemic in Turkey. Perspectives in Psychiatric Care, 57(3), 1126-1136. https://doi.org/10.1111/ppc.12666

Alnazly, E., Khraisat, O. M., Al-Bashaireh, A. M., \& Bryant, C. L. (2021). Anxiety, depression, stres, fear and social support during COVID-19 pandemic among Jordanian healthcare workers. PLoS ONE, 16 (3 March). https://doi.org/10.1371/journal.pone.0 247679

Aly, H. M., Nemr, N. A., Kishk, R. M., \& Elsaid, N. M. A. bakr. (2021). Stres, anxiety and depression among healthcare workers facing COVID-19 pandemic in Egypt: A cross-sectional online-based study. BMJ Open, 11(4), 1-7. https://doi.org/10.1136/bmjopen2020-045281

Babore, A., Lombardi, L., Viceconti, M. L., Pignataro, S., Marino, V., Crudele, M., Candelori, C., Bramanti, S. M., \& Trumello, C. (2020). Since January 2020 Elsevier has created a COVID19 resource centre with free information in English and Mandarin on the novel coronavirus COVID- 19. The COVID-19 resource centre is hosted on Elsevier Connect, the company, $s$ public news and information. January.

Bonanno GA. (2004). Loss, trauma, and human resilience. Have we underestimated the human capacity to thrive after aversive events? Am Psychol Assoc. 59(1):20-28. doi:10.1037/0003-066X.59.1.20

Boyacı, K., Şensoy, F., Beydağ, K. D., \& Kiyak, M. (2014). Stres and Stres Management in Health Institutions. Procedia - Social and Behavioral Sciences, 152, 470-475. https://doi.org/10.1016/j.sbspro.2014 .09 .233

Chekole, Y. A., Minaye, S. Y., Abate, S. M., \& Mekuriaw, B. (2020). Perceived Stres and Its Associated Factors during COVID-19 among Healthcare Providers in Ethiopia: A CrossSectional Study. Advances in Public Health, 2020. https://doi.org/10.1155/2020/5036861 Chua, G. T., Tung, K. T. S., Kwan, M. Y. W., Wong, R. S., Chui, C. S. L., Li, X., Wong, W. H. S., Tso, W. W. Y., Fu, K. W., Chan, K. L., Wing, Y. K., Chen, E. Y. H., Chun Lee, T. M., Rao, 
N., Chan, G. C. F., Hon, E. K. L., Hung, I. F. N., Lau, K. K., Ho, M. H. K., ... Ip, P. (2021). Multilevel Factors Affecting Healthcare Workers' Perceived Stres and Risk of Infection During COVID-19 Pandemic. International Journal of Public Health, 66(March), 1-9. https://doi.org/10.3389/ijph.2021.599 408

Clark, A. M. (2020). Since January 2020 Elsevier has created a COVID-19 resource centre with free information in English and Mandarin on the novel coronavirus COVID- 19. The COVID19 resource centre is hosted on Elsevier Connect, the company's public news and information. January.

Cohen, J., \& Meulen, Y. Van Der. (2020). Since January 2020 Elsevier has created a COVID-19 resource centre with free information in English and Mandarin on the novel coronavirus COVID- 19 . The COVID-19 resource centre is hosted on Elsevier Connect, the company' s public news and information. Preventative Medicine, 141(January).

Dyrbye, L. N., Shanafelt, T. D., Johnson, P. O., Johnson, L. A., Satele, D., \& West, C. P. (2019). A cross-sectional study exploring the relationship between burnout, absenteeism, and job performance among American nurses. BMC Nursing, 18(1), 1-8. https://doi.org/10.1186/s12912-0190382-7

Elshaer, N. S. M., Moustafa, M. S. A., Aiad, M. W., \& Ramadan, M. I. E. (2018). Job Stres and Burnout Syndrome among Critical Care Healthcare Workers. Alexandria Journal of Medicine, 54(3), 273-277. https://doi.org/10.1016/j.ajme.2017.0 6.004

Embriaco N, Papazian L, Kentish-Barnes N, Pochard F, Azoulay E. (2007).Burnout syndrome among critical care healthcare workers. Curr
Opin Crit Care. 13:482-488. doi: 10.1097/MCC.0b013e3282efd2 $8 \mathrm{a}$

Garciá-Fernández, L., Romero-Ferreiro, V., López-Roldán, P. D., Padilla, S., Calero-Sierra, I., Monzó-Garciá, M., Pérez-Martín, J., \& RodriguezJimenez, R. (2020). Mental health impact of COVID-19 pandemic on Spanish healthcare workers. Psychological Medicine, 3, 17-19. https://doi.org/10.1017/S0033291720 002019

Gheshlagh RG, Sayehmiri K, Ebadi A, et al. (2017). The relationship between mental health and resilience: a systematic review and metaanalysis. Iran Res Crescent Med J. 31.

Hosseinzadeh-Shanjani, Z., Hajimiri, K., Rostami, B., Ramazani, S., \& Dadashi, M. (2020). Stres, anxiety, and depression levels among healthcare staff during the COVID-19 epidemic. Basic and Clinical Neuroscience, 11(2), 163-170. https://doi.org/10.32598/bcn.11.covid 19.651 .4

Huang, L., Wang, Y., Liu, J., Ye, P., Chen, X., Xu, H., Guo, Y., Qu, H., \& Ning, G. (2021). Short report: factors determining perceived stres among medical staff in radiology departments during the COVID-19 outbreak. Psychology, Health and Medicine, 26(1), 56-61. https://doi.org/10.1080/13548506.202 0.1837390

Kandeger, A., Guler, H. A., Egilmez, U., \& Guler, O. (2018). Major depressive disorder comorbid severe hydrocephalus caused by Arnold Chiari malformation Does exposure to a seclusion and restraint event during clerkship influence medical student 's attitudes toward psychiatry? Indian Journal of Psychiatry, 59(4), 20172018.

https://doi.org/10.4103/psychiatry.Ind ianJPsychiatry 
Larson, E. L., Liverman, C. T., \&

Respiratory, O. V. (2011). Preventing

Transmission of Pandemic Influenza and Other Viral Respiratory Diseases. In Preventing Transmission of Pandemic Influenza and Other Viral Respiratory Diseases. https://doi.org/10.17226/13027

Leng, M., Wei, L., Shi, X., Cao, G., Wei, Y., Xu, H., Zhang, X., Zhang, W., Xing, S., \& Wei, H. (2021). Mental distres and influencing factors in nurses caring for patients with COVID-19. Nursing in Critical Care, 26(2), 94-101. https://doi.org/10.1111/nicc.12528

Lenzo, V., Quattropani, M. C., Sardella, A., Martino, G., \& Bonanno, G. A. (2021). Depression, anxiety, and stres among healthcare workers during the COVID-19 outbreak and relationships with expressive flexibility and context sensitivity. Frontiers in Psychology, 12(February), $1-9$. https://doi.org/10.3389/fpsyg.2021.62 3033

Maraqa, B., Nazzal, Z., \& Zink, T. (2020). Palestinian Health Care Workers' Stres and Stresors During COVID-19 Pandemic: A Cross-Sectional Study. Journal of Primary Care and Community Health, 11. https://doi.org/10.1177/21501327209 55026

Mohd Fauzi, M. F., Mohd Yusoff, H., Muhamad Robat, R., Mat Saruan, N. A., Ismail, K. I., \& Mohd Haris, A. F. (2020). Doctors' Mental Health in the Midst of COVID-19 Pandemic: The Roles of Work Demands and Recovery Experiences. International Journal of Environmental Research and Public Health, 17(19), 7340.

MHPSS Reference Group. (2020). Catatan Tentang Aspek Kesehatan Jiwa dan Psikososial Wabah Covid. Iasc, Feb, 1-20.

Nguyen, N. P. T., Le, D. D., Colebunders, R., Siewe Fodjo, J. N., Tran, T. D., \& Van Vo, T. (2021). Stres and associated factors among frontline healthcare workers in the COVID-19 epicenter of da nang city, vietnam. International Journal of Environmental Research and Public Health, 18(14). https://doi.org/10.3390/ijerph1814737 8

Pandey, A., Sharma, C., Chapagain, R. H., Devkota, N., Ranabhat, K., Pant, S., \& Adhikari, K. (2021). Stres, Anxiety, Depression and Their Associated Factors among Health Care Workers During COVID -19 Pandemic in Nepal. Journal of Nepal Health Research Council, 18(4), 655-660. https://doi.org/10.33314/jnhrc.v18i4.3 190

Rossi, R., Socci, V., Pacitti, F., Di Lorenzo, G., Di Marco, A., Siracusano, A., \& Rossi, A. (2020). Mental Health Outcomes among Frontline and Second-Line Health Care Workers during the Coronavirus Disease 2019 (COVID-19) Pandemic in Italy. JAMA Network Open, 3(5), 2019-2022. https://doi.org/10.1001/jamanetworko pen.2020.10185

Şahin, M. K., Aker, S., Şahin, G., \& Karabekiroğlu, A. (2020). Prevalence of Depression, Anxiety, Distres and Insomnia and Related Factors in Healthcare Workers During COVID19 Pandemic in Turkey. Journal of Community Health, 45(6), 11681177. https://doi.org/10.1007/s10900020-00921-w

Shahrour, G., \& Dardas, L. A. (2020). Acute stres disorder, coping selfefficacy and subsequent psychological distres among nurses amid COVID19. Journal of Nursing Management, 28(7), 1686-1695. https://doi.org/10.1111/jonm.13124

Sota, T. (2003). Online First publication. Population Ecology, 45(2), 59. https://doi.org/10.1007/s10144-0030153-9

Wilson, W., Raj, J. P., Rao, S., Ghiya, M., Nedungalaparambil, N. M., Mundra, 
H., \& Mathew, R. (2020). Prevalence and Predictors of Stres, anxiety, and Depression among Healthcare Workers Managing COVID-19 Pandemic in India: A Nationwide Observational Study. Indian Journal of Psychological Medicine, 42(4), 353-358.

https://doi.org/10.1177/02537176209 33992

World Health Organization. (2020). In WHO Global Pulse Survey, $90 \%$ of Countries Report Disruptions to Essential Health Services since COVID-19 Pandemic.

Xiang, Y. T., Yang, Y., Li, W., Zhang, L., Zhang, Q., Cheung, T., \& Ng, C. H. (2020). Timely mental health care for the 2019 novel coronavirus outbreak is urgently needed. The Lancet Psychiatry, 7(3), 228-229. https://doi.org/10.1016/S22150366(20)30046-8

Yadav, U. N., Yadav, O. P., Singh, D. R., Ghimire, S., Rayamajhee, B., Mistry, S. K., Rawal, L. B., Ali, A. M., Tamang, M. K., \& Mehta, S. (2021). Perceived fear of COVID-19 and its associated factors among Nepalese older adults in eastern Nepal: A cross-sectional study. PLOS ONE, $16(7$ https://doi.org/10.1371/journal.pone. 0254825

Zhang, J., Lu, H., Zeng, H., Zhang, S., Du, Q., Jiang T. The Differential Psychological Distres of Populations Affected by the COVID-19 Pandemic. 2020;(January) 